\title{
Role orientations in university and school student youth (based on a sociological study)
}

\section{Orientações de papéis em estudantes universitários e escolares (com base em um estudo sociológico)}

\section{Orientaciones de roles en jóvenes estudiantes universitarios y escolares (basado en un estudio sociológico)}

\author{
Vasiliy Nikolaevich Stegniy ${ }^{1}$ (D) Lyudmila Nikolaevna Kurbatova $^{1}$ (iD, \\ Konstantin Anatolievich Antipyev ${ }^{1}$ iD , Milana Borisovna Kolesnichenko ${ }^{1}$ (D), \\ Sergey Natanovich Smolnikov ${ }^{1}$ iD \\ ${ }^{1}$ Perm National Research Polytechnic University, Perm, Russian Federation. \\ Corresponding author: \\ Vasiliy Nikolaevich Stegniy \\ Email: socio@pstu.ru
}

How to cite: Stegniy, V. N., Kurbatova, L. N., Antipyev, K. A., Kolesnichenko, M. B., \& Smolnikov, S. N. (2021). Role orientations in university and school student youth (based on a sociological study). Revista Tempos e Espaços em Educação, 14(33), e16265. http://dx.doi.org/10.20952/revtee.v14i33.16265

\begin{abstract}
The present study examines social roles as a category of sociological science, as well as their role, content, and place in the inner world of a person. Civilizational and cultural changes and changes in social systems including the status and structural alterations lead to modifications in the paradigm of a "social role" and the content of role behavior. The emergence of new phenomena in individuals' role preferences is to a certain extent determined by the development of the innovation and information space of modern society. This effect is most prominent among young people characterized by a positive attitude to various social changes. Sociological studies conducted among students and pupils in grades 10-11 show the degree of young people's involvement in specific social roles and the nature of the priority of their choice. The conducted comparative analysis shows the peculiarities of role structure in each group of young people and allows determining the relationship between social statuses and role preferences. Young people's assessment of the influence of market relations on their role preferences is examined and the peculiarities of this influence are emphasized. Young people's understanding of the functions of the state in modern Russian society in shaping social roles, as well as their attitude to moral norms and social and legal laws are highlighted. The study proposes a typology of life roles of school students in grades 10-11 and university students.
\end{abstract}

Keywords: Social role. Social status. Personality. Role preferences. Role behavior. 


\section{RESUMO}

O presente estudo examina os papéis sociais como uma categoria da ciência sociológica, bem como seu papel, conteúdo e lugar no mundo interior de uma pessoa. Mudanças civilizacionais e culturais e mudanças nos sistemas sociais, incluindo o status e as alterações estruturais, levam a modificações no paradigma de um "papel social" e no conteúdo do comportamento do papel. O surgimento de novos fenômenos nas preferências de papel dos indivíduos é, em certa medida, determinado pelo desenvolvimento do espaço de inovação e informação da sociedade moderna. Este efeito é mais proeminente entre os jovens, caracterizados por uma atitude positiva em relação a várias mudanças sociais. Estudos sociológicos realizados entre alunos e alunos das séries 10-11 mostram o grau de envolvimento dos jovens em papéis sociais específicos e a natureza da prioridade de sua escolha. A análise comparativa realizada mostra as peculiaridades da estrutura de papéis em cada grupo de jovens e permite determinar a relação entre status sociais e preferências de papéis. A avaliação dos jovens sobre a influência das relações de mercado em suas preferências de papel é examinada e as peculiaridades dessa influência são enfatizadas. A compreensão dos jovens sobre as funções do Estado na sociedade russa moderna na formação de papéis sociais, bem como sua atitude em relação às normas morais e às leis sociais e legais são destacadas. $O$ estudo propõe uma tipologia de papéis de vida de alunos de escolas nas séries 10-11 e estudantes universitários.

Palavras-chave: Papel social. Status social. Personalidade. Preferências de função. Comportamento de papel.

\section{RESUMEN}

El presente estudio examina los roles sociales como una categoría de la ciencia sociológica, así como su rol, contenido y lugar en el mundo interior de una persona. Los cambios de civilización y cultura y los cambios en los sistemas sociales, incluido el estado y las alteraciones estructurales, conducen a modificaciones en el paradigma de un "rol social" y el contenido del comportamiento del rol. La aparición de nuevos fenómenos en las preferencias de roles de los individuos está determinada en cierta medida por el desarrollo del espacio de innovación e información de la sociedad moderna. Este efecto es más prominente entre los jóvenes que se caracterizan por una actitud positiva ante diversos cambios sociales. Los estudios sociológicos llevados a cabo entre estudiantes y alumnos de los grados 10-11 muestran el grado de participación de los jóvenes en roles sociales específicos y la naturaleza de la prioridad de su elección. El análisis comparativo realizado muestra las peculiaridades de la estructura de roles en cada grupo de jóvenes y permite determinar la relación entre los estados sociales y las preferencias de roles. Se examina la evaluación de los jóvenes de la influencia de las relaciones de mercado en sus preferencias de roles y se enfatizan las peculiaridades de esta influencia. Se destaca la comprensión de los jóvenes de las funciones del Estado en la sociedad rusa moderna en la configuración de los roles sociales, así como su actitud hacia las normas morales y las leyes sociales y legales. El estudio propone una tipología de los roles de vida de los estudiantes de la escuela en los grados 10-11 y los estudiantes universitarios.

Palabras clave: Papel social. Estatus social. Personalidad. Preferencias de rol. Comportamiento de rol.

\section{INTRODUCTION}

When social relations undergo transformations under the influence of technological, political, and economic change, young people are the most affected as it changes their hierarchy of social roles. This is especially true for the generations of young people living under the conditions of a rapid change in the social paradigm of these relations.

The change in the type of society has a significant impact on the personality and leads to changes in social roles and role behavior. The formation of information and network society raises 
the question of the role of personality and its social role structure (Stegnii, 2015). The most rapid change in role orientations occurs in youth as a highly socially mobile group.

The sociological study of role orientations in young people allows predicting the possible behavior of young people in terms of creating their life strategies and awareness of their place in society and social groups.

Being a dynamic group, young people perceive the changes taking place in society most acutely and relate to them. Such dynamics are inherent both in the intensive development of society itself and in the socio-psychological characteristics of young people themselves.

In our opinion, student youth presents the greatest interest. While university students are studied quite frequently, school students are somewhat "neglected" by researchers. At the same time, it is in high school that more stable life plans are formed and identification with certain social statuses and social groups takes place.

It should be noted that such a component of personality structure as a social sore has been researched in sociology quite poorly in recent decades. In the figurative expression of I. Shubrt (2017), the category of a social role has been a forgotten topic of sociological science.

In preceding historical periods, role orientations were less mobile and formed stable hierarchies. New phenomena in individuals' role preferences manifest in the formation of the modern innovation and information society (Stegnii, 2017; Toshchenko, 2008). This change reveals itself in the blurring of social orientations for certain professions, types of activities, and family roles. Most often, it is associated with the gender approach and is characteristic of both European culture and Asian culture (Adachi, 2018). Young people experience less and less pressure from their elders and the decreasing continuity of values many of which they consider obsolete. Such cultural metamorphoses are defined by L.N. Kurbatova (2012) as the "surrogate culture".

Knowledge of the structure of social roles developing in the minds of young people can be used for social work with young people and the construction of youth policy.

\section{METHODS}

The data presented in the study was obtained in the course of two sociological studies conducted in the first half of 2017. The first empirical sociological survey was conducted among the students of Perm National Research Polytechnic University and included 754 respondents enrolled in various faculties and educational programs, both humanitarian and technical. The optimal choice was to conduct a quantitative survey accounting for the peculiarities of the object of the study (Cicourel, 1964; Duncan, 1966).

Aside from the specialty, the key parameters of the sample included gender, age, year of study, the level of personal and family income, the place of residence before entering the university, and several other factors. In our view, the selected factors are the leading in the disclosure of the chosen problem (ladov, 2003). Respondents represent the leading higher educational institution in the region typical for the non-capital regions of the country.

The second empirical study was conducted among high school students in general education schools. High school students were defined as students in grades 10-11 of Perm Krai schools $(\mathrm{N}=258)$.

Primary information was collected via a personal formalized questionnaire survey filled out at the place of study of the respondents. The return rate of the questionnaires was $96.6 \%$. The sample is representative and reproduces the main parameters of the general population.

The analysis of the study results accounted for such peculiarities of social mobility as the socio-territorial and socio-organizational change in the status of young people, the transition from school student status to university student status, and moving to the regional center where the university is located. The primary socialization of $65 \%$ of the respondents took place in a small town 
or rural area, every fourth respondent went through primary socialization in a big city, and residents of the regional center accounted for $10 \%$ of the sample.

During the study, the respondents were asked questions about their role identification, role preferences, attitudes toward inequality, life plans, etc. Answers to the questions revealed the role structure of students and young adults involved in the study.

\section{THEORETICAL BACKGROUND}

The youth started to be considered as an object of sociological analysis most closely during the period of "student revolutions" of the late 1960s and early 1970s. Not only the scientific environment but also society generally became aware of the growing generational differences and behavioral patterns in youth and older generations (Dwyer \& Wyn, 2001; Petukhov et al., 2003; Zhuravleva, 2006).

Youth as a social group is examined from the standpoint of three predominant paradigms: the biological, the social, and the cultural (Weinstein, 1994; Galland, 2006). These paradigms assist in explaining the peculiarities of the social status of youth and the corresponding model of social behavior.

The social and cultural paradigms are closely intertwined. The work of M. Mead (1970) presenting youth as a part of the conflict between generations, combined the social and cultural paradigms. Mead notes that youth is less dependent on the older generations and, therefore, does not reproduce the preceding culture that does not present importance to them.

In past historical periods, young people wanted to quickly become adults, to copy the experience of adults, and the models of their behavior since they were relevant. In modern societies, the relevance of adult knowledge does not appear as obvious, hence the aggravation of intergenerational conflicts and different role orientations. A rather popular explanation of the role identification of young people utilizes postmodernist subcultural theories (Miles, 2000; Blackman, 2005; O’Donnell, 2010).

In the conditions of Russia, the transition from the Soviet cultural model to the capitalist model led, on the one hand, to a spiritual collapse and, on the other, to the emergence of a "surrogate culture". Families found themselves in cultural isolation, therefore, there emerged a "surrogate culture" involving parents characterized by the past Soviet culture and children having to assimilate new types of cultures having no analogs in the past of Russian society (Kurbatova, 2012). Thus, the primary socialization of children takes place in the context of the clash of two cultural antipodes. On the one hand, it aggravates the cultural and role choices of young people, and on the other hand, it provides them with a wide range of role behavior patterns.

Changes in the labor market and urbanization processes are changing young people's lifestyles, their identification with their families, territories, and peers (Miles, 2000; Schor, 2004; Robert, 2010). These problems are also fixed in the conditions of modern Russia. The social class structure of society, socio-territorial differences, and social status of the family limit the social status choices of school and university students (Stegnii \& Kurbatova, 2018; Svadbina \& Retivina, 2019).

Considering that the modern young generation is heavily affected by information technologies, we have to keep in mind that this factor also affects role identification (Stegnii, 2019).

Young people belong not only to communities geographically linked to certain places such as schools, colleges, universities, stores, and clubs but also to virtual, distant communities that can also generate the corresponding role identification (Mäntymäki \& Najmul Islam, 2014).

Socialization of vital social roles begins under the conditions of primary socialization when a stereotypical set of statuses with ascribed rules and norms of social behavior is imposed on children and adolescents (Konstantinovskii \& Popova, 2015). The choice of the social role is limited to the social space of the parental family, the territory of residence, and the educational institution. 
The transition from the status of a school student to the status of a university student allows young people to form their own ideas of certain social statuses and, consequently, not only make social choices of social status but also develop certain types of social and role behavior. This transition period is accompanied by a reassessment of social values that can either be reinforced becoming a social norm or become latent. Therefore, over time, social roles can create intrapersonal conflicts aimed at creation or non-destruction in relation to both the individual and the external social environment.

\section{RESULTS}

Sociological research has revealed a certain hierarchy of social roles revealed through the prism of socio-institutional statuses.

The structure of socio-institutional statuses includes the following life roles:

- Family status - a member of the parent family, a member of one's own family, parents (father/mother), children (son/daughter);

- Ethno-national status - a representative of one's ethnicity (nationality);

- Territorial status - a resident of the house one lives in, a resident of the neighborhood, a citizen of the city of Perm or Lysva;

- Organizational status - a school or university student, an employee of an enterprise or an organization, an entrepreneur;

- Political status - a Russian citizen, a party member, a citizen of the world, a patriot;

- Interpersonal status - a friend;

- Consumer status - a visitor of city institutions.

The role choice of the socio-institutional status is presented in Table 1.

Table 1. Role choice of the socio-institutional status (in \% of the number of respondents, coefficients of role choice*).

\begin{tabular}{lcccccc}
\hline \multirow{2}{*}{$\begin{array}{l}\text { Social and institutional } \\
\text { status }\end{array}$} & \multicolumn{3}{c}{ University students } & \multicolumn{3}{c}{ School students } \\
\cline { 2 - 7 } Family status & SM & CRC OF & CRC SF & SM & CRC OF & CRC SF \\
\cline { 2 - 7 } Ethno-national status & 46.7 & 2.12 & 2.07 & 49.7 & 2.15 & 1.94 \\
Territorial status & 45.7 & 2.21 & 2.16 & 55.2 & 2.37 & 2.19 \\
Organizational status & 26.7 & 1.79 & 1.77 & 57.5 & 2.35 & 2.15 \\
Political status & 32.5 & 1.85 & 1.82 & 35.0 & 1.85 & 1.67 \\
Interpersonal status & 31.5 & 1.90 & 1.87 & 42.4 & 2.09 & 1.90 \\
Consumer status & 75.9 & 2.71 & 2.65 & 63.6 & 2.56 & 2.39 \\
\hline
\end{tabular}

*Note: SM - social mass of the high degree of involvement in life roles of socio-institutional status, \% calculated from the number of respondents based on the aggregate indicator of social status. CRC OF - coefficient of role choice characterizing the object field of the socio-institutional status calculated from the number of respondents. CRC SF coefficient of role choice characterizing social fluctuation calculated from the number of references to the aggregate indicator of life roles accounting for the nature of the object field of institutional statuses. (Methodology of analysis developed by L.N. Kurbatova)

Social and role stability is characteristic of the family and organizational social statuses. Nevertheless, some decline in the significance of role positions is present in them as well. Social deformation is observed in the vast majority of institutional statuses: ethno-national, territorial, political, interpersonal, and consumer. The interpersonal status becomes more demanded while in other cases the role preferences deteriorate.

The difference between the coefficients of social fluctuation and object field of role choice in school students shows that youth have weak role connections with their institutional status. This 
suggests that school students do not fully identify the social role they choose with their social status. School students' institutional status-role preferences are intuitive and formalized. They are guided by the standard of the social status models offered to them. University students, on the contrary, correlate the role choice with the institutional status, therefore, their social identification is more obvious (Figure 1).

Figure 1. Problem field of the status-role preferences of school and university students (difference between CRC SF and CRC OF).

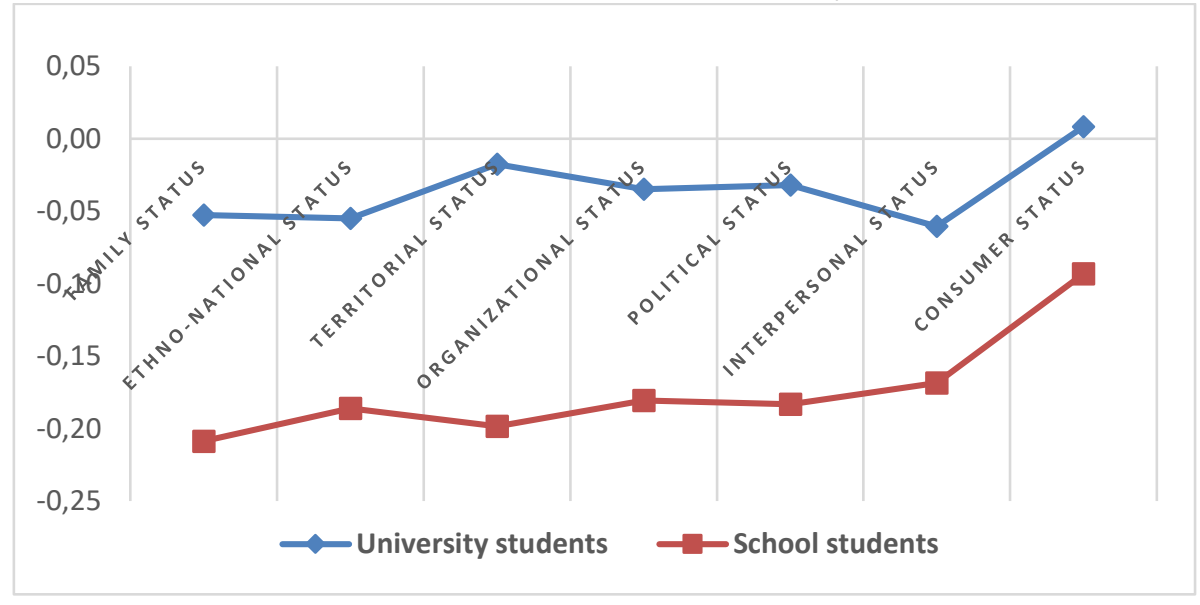

At first glance, school and university students represent a single youth group and their age differences are not that pronounced as their age ranges from 17 to 20 years old. However, their understanding and awareness of the social choice can be clearly differentiated. We recognize this aspect as the problem sphere in the status and role preferences in these categories of youth.

The degrees of preference for life roles in the studied groups studied have certain specific features determined by both objective and subjective factors.

In this regard, we conduct a comparative analysis of the structure of life role preferences in school and university students.

The most preferred life roles of university and school students are associated, first, with ascribed statuses - son/daughter, a member of the parental family. Second, they are related to the independent choice of such social roles as a school/university student or a friend. These role preferences fully coincide with the social statuses that school and university students occupy at present.

The vast majority of respondents perceive the roles of school and university students positively ( $88.4 \%$ and $76.1 \%$, accordingly). At the same time, every fifth university student has some hesitation in choosing this status ( $22.0 \%$ vs. $8.9 \%$ in school students). This suggests that as university students, young people have a more conscious approach to understanding the importance and necessity of this social role for themselves. This aspect can be the cause of a certain number of students being expelled from universities.

When it comes to predicting one's family status, both school and university students demonstrate an ambiguous role choice. While half of school and university students plan to start a family, over $3 / 4$ of the respondents are not ready to take on the role of a parent. In addition, this proportion is a little higher in school students ( $85.2 \%$ against $76 \%$, accordingly). Naturally, this result is determined by the participants' age, social status, and the level and nature of initial socialization.

At the same time, it is necessary to consider that the transition from the status of a school student to the status of a university student is gradual in modern Russia, that is, $96 \%$ of students are people who have just graduated from school. Therefore, some increase in the number of those who are focused on the role of a "family person" accompanied by a fairly high percentage of those who are not yet focused on this role characterizes the continuity of the adolescent subculture. 
The sharp transformation in role preferences is observed both the micro- and micromicro-levels, i.e. in relation to social and territorial belonging. Territorial role identity is more pronounced among school students which is natural for this social group as their primary socialization is linked to their parental family and educational socialization in school conditions which are linked to their place of residence by the status definition. While half of the school students (48.1\% and $52.2 \%$, respectively) is aware of themselves as a resident of the city and microdistrict, only $20 \%$ to $25 \%$ of university students identify themselves in this way.

It is worth noting that identification with one's living socio-territorial space turned out to be largely illusory. Specifically, $47.5 \%$ of university students no longer associate themselves with the status of a resident of their neighborhood (against $21.6 \%$ of school students). Moreover, every third university student is uncertain about their social role (31.8\%).

The situation regarding one's belonging to the city is also changing. While about $40 \%$ of both school and university students retain a weak connection to this status, the percentage of young people who show some hesitation regarding the value of belonging to the city grows from $17.4 \%$ in school students to $34.2 \%$ in university students.

Here arises one highly important issue. In Russian cultural tradition, "home" is always associated with the "family", and vice versa, "family" is tied to "home". However, the study reveals substantial transformations in this traditional social association. While $72 \%$ of school students do experience a vital connection to the house they live in, only $32.9 \%$ of university students retain this sense of belonging. Every third university student shows either instability of this relationship or a break with this status (33.4\% and $32.9 \%$, respectively). The volatility of this indicator suggests that this cultural tradition is still preserved in the minds of young people. At the same time, the urbanization of social life takes the "home-housing" beyond the "home-family" replacing its status from a social value to that of a social factor.

The concept of "home" or "place of residence" is closely tied to the social phenomenon of "friendship". Conditions of primary socialization are important factors forming the basic cultural and moral foundations of formal and informal communications of children and adolescents. At this time, the status role choice is regulated and controlled by family and the system of educational institutions. However, the choice of friends is the child's prerogative since although it is subject to external control and sometimes pressures, the priority of the choice remains with the child. The present study demonstrates this fact very clearly. Perception of oneself as a friend is vividly demonstrated by $63.6 \%$ and $75.9 \%$ of school and university students, respectively. At the same time, each third school student finds themselves in a state of uncertainty (28.7\%) while only every fifth university student experiences this feeling (19.6\%). The number of those alienated from this status is minimal ( $7.7 \%$ and $4.5 \%$ of school and university students, respectively).

It is worth noting that self-identification as a member of the parent family and as a friend formed under the conditions of initial socialization end up being quite stable in most respondents, however, a certain transformation of these social roles is observed in some study participants with the transition from the status of a school student to the status of a university student.

Socio-political and socio-ethnic affiliation serves as a powerful stimulus for the formation of young people's civic positions. However, while at the school level these stimuli perform their propaganda and advocacy role, their influence weakens outside of the closed and politically formalized educational process. For example, $73.3 \%$ of school students reported a high level of selfidentification as a Russian citizen, and only every second university student retained this attitude toward their political role (56.8\%). At the same time, every third university student is uncertain about their choice of this role (28.6\%).

One of the indicators of civic activity is membership in a political organization or participation in community activities. This social role is chosen by every tenth school student and only $3.4 \%$ of university students. Of course, we can highlight that university students are overloaded with study 
activities as it is currently their primary role and, therefore, they lack time for participation in political life. However, many students combine study and work hence they are already embedded in certain labor relations reflecting the socio-economic and social-class problems of contemporary Russian society. Therefore, the political activity of university and school students in recent years most often manifests in their participation in protests (Kurbatova, 2018).

On the other hand, the absence of a youth social and political organization tasked with the political socialization of young people in contemporary Russian society leads to youth being unready to participate in the socio-political life of the country and perform their political role.

Of course, university students' role preferences are predetermined by their status and social maturity and are interconnected with their life strategies (Tishkov et al., 2014), new phenomena in value orientations (Bannikova et al., 2013; Pavlov \& Anisimov, 2016). Meanwhile, among school students, the choice of political roles is associated, on the one hand, with the socio-psychological features of their age group and, on the other hand, with the socio-political uncertainty of their social status.

At the same time, it is questionable whether or not we can conclude that university students have a developed clear position regarding these socially significant roles and do fulfill them realizing themselves in the status of "the citizen of the country".

Certain problems are also observed in relation to the stability of the factor of ethno-national identity. The significance of this social role decreases to a certain extent $(55.2 \%$ of school students against $45.7 \%$ of university students). Compared to other social status roles, this is the highest degree of identification stability. At the same time, a rise in the number of those less focused on this social role is observed with the transition to the university student status (24.6\% against $18.1 \%$ of school students). If we consider the share of undecided individuals, the problem field expands even further affecting every second university student and close to a half of school students.

This observation is also supported by school and university students' attitudes towards the concept of "patriotism" as one of the important social roles ( $37.8 \%$ and $27.9 \%$, respectively). Every fifth school and university student reports a weak connection with this social status. On the other hand, this social role appears to be transitioning into the latent state in more than $40 \%$ of university students. It is necessary to take into account that the concept of "patriotism: is closely connected with the concept of "small Motherland", i.e. with the concept of "home-family", the primary settlement. As the study shows, this life value has also transitioned into the latent state.

Therefore, we can state that under certain conditions, this role can be demanded by young people. The only question is how they will "fulfill" this role, what social, sociopolitical vector they will choose, and whether it will be aimed at creation or destruction.

No significant transformations are observed in the socially significant role of "the citizen of the world". While at the level of primary socialization, this phenomenon is experienced by $46.5 \%$ of school students, later on, it is preserved in $37.9 \%$ of university students. This status loses all significance for every third school or university student (32.1\% vs. $22.3 \%$ of school students), however, approximately the same share of school and university students have ambiguous awareness of this role (31.2\% and $30.0 \%$, respectively).

Based on these data, we can conclude on the absence of a systematic approach in the upbringing of patriotism and citizenship among the young generation.

The formation of civil and political culture is closely connected with young people's understanding and awareness of their organizational and labor roles, i.e. the role of the consumer, the worker, and the taxpayer.

The respondents' age and organizational status indicate that they are already incorporated into the system of consumer relations. However, a different picture is observed in reality. The transformation of this role is quite apparent in university students and is negative. While every fifth school student reports high identification with this role, only every eighth university student does 
so as well ( $19.7 \%$ and $13.8 \%$, respectively). The lack of self-identification with this role was noted by $27.1 \%$ of school students and $39.8 \%$ of university students. $46.4 \%$ of university students and $42.9 \%$ of school students are undecided regarding these roles. The level of fluctuation here is the highest. Of the entire system of life roles, it is commensurate in the nature of uncertainty (latency) only with the indicator of "patriotism".

The respondents' perceptions of themselves as workers embedded in industrial relations seem to be transferred to the future. Both school and university students have this sort of attitude to this life role. Only every tenth respondent in both groups identifies with this role. The majority of respondents think about it least of all (68.9\% and $64.9 \%$, respectively). The latent state in relation to this role is demonstrated by $20 \%$ of school students and $23.4 \%$ of university students.

A similar situation is observed with respect to the role choice of the status of the entrepreneur, the owner of one's own business. However, the situation here is even more discouraging. In the socio-economic conditions prioritizing private property and market relations, young people reject the main principle of capitalism, the development of entrepreneurship, at the level of primary socialization. Thus, $79.0 \%$ of school students and $74.6 \%$ of university students are less oriented on this role. Only every tenth university student tries on this status $(9.6 \%$ vs. $5.4 \%$, respectively).

Analyzing the role preferences of 2-3 year university students in a million city and school students in grades 10-11 in a medium-sized city, we observe some differences between their role preferences which suggests that school students have more overestimated and idealized role preferences compared to university students.

Therefore, a lot of the process of role preference development is contingent on the way young people perceive modern society the essence of which is shaped by labor relations and the understanding of "the market" and "the state" as socio-economic and socio-political phenomena.

Around $3 / 4$ of the surveyed school students highlighted the freedom for initiative, entrepreneurship, the society of independent producers, and the path to prosperity in the essence of the market which is all true but the role of these factors of the market is largely overestimated (65.6\% and $71.9 \%$, accordingly). These meanings appear to be predominant in the market society at first glance, however, the question is whether or not they resolve the processes taking place in the modern post-industrial information and innovation society. They most certainly do not. Since nothing else is offered, it is no coincidence that one in five school and university students alike perceive today's market as a given that cannot be changed ( $20.6 \%$ and $23.3 \%$, respectively).

A comparative analysis of respondents' opinions about the "market" as a form of social relations and their own role choice of the status of an "entrepreneur" and "a business owner" shows that, on the one hand, school and university students have a mythologized perception of the capitalism model offered by the political system and, on the other hand, the reality (Petrov, 2017) does not contribute to the acceptance of this model as a signal to action by the respondents.

The dynamics of the market and society will depend on the place of the individual in it and the regulatory role of the state in these processes. The modern state as a political system and the market do not oppose but complement each other.

University and school students share the same perception of the place and role of the state in human and social life. Young people correctly understand that the state has to be the main guarantor of both work and material and social status $(60.5 \%$ and $55.9 \%$, respectively). This guarantee to everyone is fixated in the main normative document for both the society, the state, and the individual. School and university students rightly note that state assistance has to be targeted at the special unprotected population groups - disabled people, old people, children, and other groups ( $18.2 \%$ and $20.4 \%$, respectively). Every fifth school and university student believes that a person "should rely on themselves and not the state", this was noted by every fourth respondent in both groups ( $21.3 \%$ and $23.6 \%$, respectively). This can primarily refer to those who are financially 
secure, i.e. people who can be considered socially protected. However, these people also need clear guarantees from the state concerning their status and activities.

Modern social, scientific and educational, territorial and geographical, environmental, migration, and information and technology trends require the formation of a new model of social structure. This raises the question of a new model of the state. At the same time, a new model of social structure can only be implemented and developed by the state, and then by other political and social institutions. The hypothesis - "the social state - a developed society" is currently realized in the most developed countries of the world.

Personal role preferences develop based on moral values laid down at a young age. In this regard, the attitude of school students in grades 10-11 and university students to moral norms and their place and role in the future life of young people is very revealing. The following answers were given to the question "Do you think it is possible to achieve success in life without violating laws and moral norms?"

No fundamental differences were found between the respondents of both groups on this question. Every tenth respondent believes that one cannot achieve success in life without violating laws and moral norms (9.7\% and $7.9 \%)$; every third respondent thinks that one can hardly achieve success in life without violating laws and moral norms (28.9\% and $33.7 \%) ; 60 \%$ of respondents believe that one cannot violate laws and moral norms.

This observation indicates the current state of the moral atmosphere in society as a whole and the state of moral education in general education schools and universities. The obtained results are consistent with other sociological studies, i.e. are typical for the way of life, value priorities, and moral values of young people in modern Russia (Gorshkov et al., 2007; Beliaeva, 2010).

\section{CONCLUSION}

In our study of the role preferences of secondary school students in grades 10-11 and university students, we clearly show that both social groups of young people develop a preference not for a single role but for a whole system of roles which indicates the level of their social maturity.

To some extent, young people do have institutional attitudes towards the system of social statuses offered to them by contemporary Russian society. At the same time, we cannot conclude that school and university students are equally ready to perform their social roles in accordance with their preferred status. Contradictions between role preferences and real life differ between the groups, thus, the level of school and university students' readiness to perform their social roles in modern society is more latent.

The transition from the schoolroom to the university classroom is accompanied by major social transformations in young people's ideas about their role in both their personal lives and society.

It should be noted that a more stable identification with family and role functions, ethnonational culture, and interpersonal culture of communication is formed in the conditions of primary socialization.

Socio-territorial status has a strong influence on young people's choice of certain social roles.

At the same time, urbanization processes are destroying the territorial-settlement identity, therefore, serious transformations of the traditional socio-settlement culture take place in the social reality.

Institutions of politics and economics do not fulfill their social mission of forming a civic, political, organizational, and labor identity in young people.

The study identified four groups according to the degree of school and university students readiness to perform life roles.

The first group - school and university students whose role preferences coincide with trends in modern society. 
The second group - school and university students demonstrating partial correspondence of role preferences to trends in the development of the information and innovative society.

The third group - school and university students whose role preferences do not correspond to the prospects of development of modern society.

The fourth group - school and university students with undeveloped role preferences. The presence of this group is no surprise as some people develop role preferences at the age of 18-20 years old, some form them at 20-25 years old, and in some people, their formation occurs at the age of 26-30 years old or later. The specific time period is contingent on the process of a person's socialization and individualization.

The formation of role preferences in young people in accordance with the trends of the development of modern Russian society presents the most important strategic objective of the state.

Authors' Contributions: Vasiliy Nikolaevich Stegniy: conception and design, acquisition of data, analysis and interpretation of data, drafting the article, critical review of important intellectual content. Lyudmila Nikolaevna Kurbatova: conception and design, acquisition of data, analysis and interpretation of data, drafting the article, critical review of important intellectual content. Konstantin Anatolievich Antipyev: conception and design, acquisition of data, analysis and interpretation of data, drafting the article, critical review of important intellectual content. Milana Borisovna Kolesnichenko: conception and design, acquisition of data, analysis and interpretation of data, drafting the article, critical review of important intellectual content. Sergey Natanovich Smolnikov: conception and design, acquisition of data, analysis and interpretation of data, drafting the article, critical review of important intellectual content. All authors have read and approved the final version of the manuscript.

Ethics Approval: Not applicable.

Acknowledgments: Not applicable.

\section{REFERENCES}

Adachi, T. (2018). Work-family planning and gender role attitudes among youth. International Journal of Adolescence and Youth, 23(1), 52-60, https://doi.org/10.1080/02673843.2016.1269655

Bannikova, L. I., Boronina, L. N., \& Vishnevskii, lu. R. (2013). Novye iavleniia v tsennostnykh orientatsiiakh uralskogo studenchestva [New phenomena in the value orientations of the Ural students]. Sotsiologicheskie issledovaniia, 2, 5868.

Beliaeva, E. V. (2010). Nravstvennye tsennosti epokhi postmoderna [Moral values of the postmodern era]. Filosofskie nauki, 1, 60-64.

Blackman, S. (2005). Youth subcultural theory: a critical engagement with the concept, its origins and politics, from the Chicago school to postmodernism. Journal of Youth Studies, 8(1), 1-20.

http://dx.doi.org/10.1080/13676260500063629

Cicourel, A. V. (1964). Method and measurement in sociology. New York, NY: The Free Press.

Duncan, O.D. (1966). Path analysis: sociological examples. American Journal of Sociology, 72(1), 1-16. https://doi.org/10.1086/224256

Dwyer, P., \& Wyn, J. (2001). Youth, education and risk: Facing the future. London: Routledge Falmer.

Galland, O. (2006). Sociologie de la jeunesse [Sociology of youth]. Paris: Armand Colin.

Gorshkov, M. K., Andreev, A. L., Anikin, V. A., Goryunova, S. V., Davydova, N. M., Zadorin, I. V., Lezhnina, Yu. P., Ovchinnikova, Yu. V., Pakhomova, E. I., Petukhov, V. V., Sedova, N. N., Tikhonova, N. E., Khromov, K. A., \& Bube, M. (2007). Molodezh novoi Rossii: obraz zhizni i tsennostnye prioritety: Analiticheskii doklad [Youth of the new Russia: way of life and value priorities: Analytical report]. Moscow: Institute of sociology RAS, 143 p.

ladov, V. A. (2003). Strategiia sotsiologicheskogo issledovaniia. Opisanie, obiasnenie, ponimanie sotsialnoi realnosti [Sociological research strategy. Description, explanation, and understanding of social reality]. Moscow: Dobrosvet, 596 p. 
Konstantinovskii, D. L., \& Popova, S. S. (2015). Zhiznennye plany shkolnikov [Life plans of schoolchildren]. Sotsiologicheskie issledovaniia, 11(379), 37-48.

Kurbatova, L. N. (2012). Zhiznennye tsennosti studentov kak institutsionalnye indikatory formatsionnogo izmeneniia obshchestva [Life values of students as institutional indicators of the formational change of society]. Alma Mater, 9 , 35-42.

Kurbatova, L. N. (2018). Vybory 2016 goda: post scriptum (po materialam sotsiologicheskogo issledovaniia studentov) [Elections 2016: post scriptum (based on a sociological study of students)]. Bulletin of the Perm National Research Polytechnic University. Socio-economic sciences, 2, 34-44. https://doi.org/10.15593/2224-9354/2018.2.4

Mäntymäki, M., \& Najmul Islam, A. K. M. (2014). Social virtual world continuance among teens: uncovering the moderating role of perceived aggregate network exposure. Behaviour \& Information Technology, 33(5), 536-547. http://dx.doi.org/10.1080/0144929X.2013.872190

Mead, M. (1970). Culture and commitment: a study of the generation gap. New York: Natural History Press.

Miles, S. (2000). Youth lifestyles in a changing world. Buckingham: Open University Press.

O’Donnell, M. (2010). Generation and Utopia: Using Mannheim's concepts to understand 1960s radicalism. Young, 18(4), 367-383. http://dx.doi.org/10.1177/110330881001800401

Pavlov, B. S., \& Anisimov, S. A. (2016). Ekonomicheskoe povedenie molodezhi na Urale: sotsialno-psikhologicheskii analiz [Economic behavior of youth in the Urals: a socio-psychological analysis]. Yekaterinburg: Institute of Economics, Ural Branch of the Russian Academy of Sciences, 603 p.

Petrov, A. (February 22, 2017). Chem grozit sotsialnoe rassloenie [What is the threat of social stratification]. Argumenty i fakty, 8, 11.

Petukhov, V. V., Smirnov, L. M., Dubov, I. G., Kurbangaleeva, E. Sh., Byzov, G. L., Solovey, T. D., Vinarsky, A. V., Khodonov, A. S., Zdravomyslova, O. M., Khvostov, A. A., \& Tyupa V. I. (2003). Bazovye tsennosti rossiian: sotsialnye ustanovki. Zhiznennye strategii. Simvoly. Mify [Basic values of Russians: social attitudes. Life strategies. Symbols. Myths]. Moscow: Dom intellektualnoi knigi, 446 p.

Robert, P. (2010). Social origin, school choice, and student performance. Educational Research and Evaluation, 16(2), 107-129. https://doi.org/10.1080/13803611.2010.484972

Schor, J. B. (2004). Born to buy. The commercialized child and the new consumer culture. New York: Scribner.

Shubrt, I. (2017). Sotsialnaia rol - zabytaia tema sotsiologii [Social role - a forgotten topic of sociology]. Sotsiologicheskie nauki, 6, 15-24. https://doi.org/10.7868/S0132162517060022

Stegnii, V. N. (Ed.). (2015). Lichnost v informatsionno-innovatsionnom obshchestve [Youth in the informationinnovative society]: monograph. Perm: Publishing House of the Perm National Research Polytechnic University, 448 p.

Stegnii, V. N. (Ed.). (2017). Kultura v informatsionno-innovatsionnom obshchestve [Culture in an informationinnovative society]: monograph. Perm: Publishing House of the Perm National Research Polytechnic University.

Stegnii, V. N. (Ed.). (2019). Molodezh v informatsionno-innovatsionnom obshchestve [Youth in the informationinnovative society]: monograph. Perm: Publishing House of the Perm National Research Polytechnic University, 388 p.

Stegnii, V. N., \& Kurbatova, L. N. (2018). Sotsialnyi portret studenchestva v usloviiakh transformatsii rossiiskogo obshchestva [Social portrait of students in the context of the transformation of Russian society]: monograph. 2nd ed. Perm: Publishing House of the Perm National Research Polytechnic University, 384 p.

Svadbina, T. V., \& Retivina, V. V. (2019). Professionalnyi vybor shkolnikov (po materialam sotsiologicheskogo issledovaniia) [Professional choice of schoolchildren (based on a sociological study)]. Azimut nauchnykh issledovanii: pedagogika i psikhologiia, 8(2(27)), 215-217. https://doi.org/10.26140/anip-2019-0802-0050

Tishkov, V. A., Barash, R. E., \& Stepanov, V. V. (Eds.). (2014). Rossiiskoe studenchestvo: identichnost, zhiznennye strategii i grazhdanskii potentsial [Russian Students: Identity, Life Strategies and Civic Potential]. Moscow: Institute of Ethnology and Anthropology RAS, 342 p.

Toshchenko, Zh. T. (2008). Paradoksalnyi chelovek [The paradoxical human]. 2nd ed., revised and supplemented. Moscow: IUNITI, 543 p.

Weinstein, D. (1994). Expendable youth: the rise and fall of youth culture. In: Epstein, J. S. (Ed.). Adolescents and their music: If it's too loud, you're too old. New York: Garland, pp. 67-86. 
Zhuravleva, N. A. (2006). Dinamika tsennostnykh orientatsii lichnosti v rossiiskom obshchestve [Dynamics of personal value orientations in Russian society]. Moscow: Institute of Psychology RAS, 334 p.

Received: 11 May 2021 | Accepted: 4 August 2021 | Published: 24 August 2021 distribution, and reproduction in any medium, provided the original work is properly cited. 